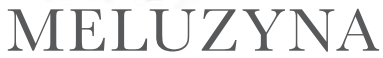

ISSN 2449-7339

2 (11) (2019) | Rocznik VI

DOI: $10.18318 /$ me.2019.2-05

KONTEKTY I NAWIAZANIA

\author{
Roksana Rał-Niemeczek* \\ Uniwersytet Opolski \\ ORCID ID 0000-0002-0438-0552
}

\title{
Rola kobiet w dramacie Pentesilea Szymona Szymonowica
}

Rola kobiet w utworach Szymona Szymonowica to temat dosyć osobliwy. W łacińskiej twórczości poety żeńskich przedstawicielek trzeba wręcz wypatrywać. Ich obecność w tekście zdaje się ledwie zaznaczona. Stąd też dramaty Castus Joseph (1587) i późniejsza Pentesilea (1618)1 istotnie wyróżniają się na tym tle, a zarazem wpasowują w panującą opinię o problematycznym stosunku autora Sielanek do płci pięknej. Już sto lat temu pisano o Szymonowicu jako o przeciwniku dążeń emancypacyjnych (Petrażycka-Tomicka, 1914, s. 37). O osobistej niechęci do kobiet, która niestosownie odcisnęła się na jego twórczości, wypowiadała się także Ewa Jolanta Głębicka. Badaczka wyjaśniła, że wybór mitycznej Pentezylei na bohaterkę tragedii może przemawiać za tym, iż wizerunek kobiety-wojownika nie budził sympatii autora, śmierć Amazonki zaś nie była traktowana jako nieszczęście, a jako kara za jej głupotę (Głębicka, 2001b, s. 152). Celem artykułu jest zbadanie przestrzeni literacko-kulturowej, w której kwestia kobieca w XVI-XVII wieku zostaje w przypadku tego utworu skonfrontowana $\mathrm{z}$ jego mizoginiczną puentą.

Chociaż spisane w języku polskim Sielanki są pomnikowym dziełem zamojskiego twórcy, to o Szymonowicu winno się raczej mówić jako o poecie łacińsko-polskim aniżeli polsko-łacińskim. Polskie utwory nie stanowią nawet połowy całej jego spuścizny. Ostatni z okresów twórczości

\footnotetext{
* e-mail autorki: ral.niemeczek@gmail.com

Praca powstała w ramach projektu badawczego Narodowego Programu Rozwoju Humanistyki „Lubelska Biblioteka Staropolska. Series Nova. Edycja krytyczna tekstów staropolskich - kontynuacja serii wydawniczej”. Nr 0082/ NPRH5/H11/84/2017.

1 Tragedia Szymonowica doczekała się kilku wersji zapisu tytułu: Pentesilea, Penthesilea, Pentezylea. W artykule będę się posługiwać wariantem tytułu: Pentesilea (w formie nominatywnej), oraz spolszczoną wersją imienia bohaterki: „Pentezylea”, którą zaproponował w przekładzie Ksawery Zubowski.
} 
Szymonowica, który Roman Pilat datuje na lata 1614-1629, obfitował w nowe teksty (co było konsekwencją faktu, że Simonides zakończył obowiązki nauczycielskie). Utwory te jednak były mniej udane i rzadziej trafiały do druku (Pilat, 1909, s. 91). Napisana w 1618 roku w Zamościu Pentesilea zalicza się do tegoż właśnie stadium twórczości, o której najmniej dyskutowano i którą najmniej ceniono. Starsi biografowie nie poświęcali temu dramatowi więcej miejsca aniżeli tylko wzmiankę. Na sam przekład, dokonany w 1778 roku przez Ksawerego Zubowskiego, trzeba było czekać aż 150 lat, podczas gdy Castus Joseph, czyli wcześniejszy dramat Szymonowica, został przetłumaczony w 1597 roku - ledwie dziesięć lat po jego wydaniu. Obecnie, w ramach projektu Lubelskiej Biblioteki Staropolskiej, trwają prace nad przekładem Pentesilea. Tłumaczenie ukaże się dzięki staraniom Elwiry Buszewicz i zawierać będzie m.in. analizę przemian nowołacińskiego dramatu z uwzględnieniem tła zarówno polskich, jak i europejskich realizacji tego gatunku. W zapowiedziach edycji Series Nova informuje się, że będzie ona ukazywała również:

[...] wpływ Giovanniego Pontana i jego naśladowców na imitację dialogu z małym dzieckiem, ukazane będzie oddziaływanie innych zachodnich twórców nowołacińskich na stylistykę polskiego dramatu. Inną istotną przestrzenią badawczą jest antropologia kultury i tzw. kwestia kobieca w XVI wieku, gdyż dramat ma do pewnego stopnia mizoginiczne przesłanie ${ }^{2}$.

Powstaje pytanie w odniesieniu do zarówno Castus Joseph, jak i Pentesilea: jak zagadnienia dotyczące kobiet w tych tekstach odnoszą się do nowożytnego dyskursu feministycznego? W jakich rolach Szymonowic obsadził niewiasty? Czy ich obecność w Pentesilea wpisuje się w „logikę dziejów”, dopełniając wizerunku matki-wychowawczyni, kształtującej umysły i siły kolejnych pokoleń? Jakie były jej aspiracje? Jaki był jej udział w budowaniu społeczeństwa i rodziny? Pytania te nasuwają się podczas lektury całego dramatu.

Pentesilea nawiązuje przede wszystkim do poematu epickiego Posthomericorum libri XIV Kwintusa ze Smyrny (Quintus Smyrnaeus, 1913), gdzie już sam tytuł wskazuje, że utwór jest uzupełnieniem Iliady. Wizerunek Pentezylei nie ogranicza się tylko do dzieła Smyrneńczyka. Pochodząca z greckiej mitologii królowa Amazonek jest córką Aresa i Otrery oraz siostrą Hipolity, Antiopei i Melanippe (Grimal, 1990, s. 286). Heroina brała udział w wojnie trojańskiej i mimo że zginęła pod murami Ilionu, zabita przez Achillesa, stała się w kulturze symbolem kobiecego udziału w tej walce. W sztukach pięknych Pentezylea zawsze ukazywana jest w pełnym rynsztunku złożonym $\mathrm{z}$ hełmu, kołczanu ze strzałami, któremu zwykle towarzyszy łuk, tarcza oraz toporek w ręku. Na niektórych malowidłach, przedstawiających bohaterkę mierzącą się z herosem, Amazonka dzierży inne przedmioty służące do walki wręcz. Przykładem niech będzie „gwiazda zaranna”, czyli typ wekiery przypominającej maczugę nabitą żelaznymi kolcami. Taki wizerunek Pentezylei prezentują malunki w stylu czerwonofigurowym, uwiecznione na naczyniach autorstwa greckiego artysty z V wieku, który swoje prace opatrywał pseudonimem „Malarz Pentezylei”. Z kolei w malarstwie średniowiecznym częstokroć przedstawiano heroinę jako kobietę walczącą na koniu. Sportretowanie Amazonki w piętnastowiecznej ikonografii francuskiej zapewniło jej miejsce pośród innych Lady Worthies,

2 https://www.umcs.pl/pl/edycje-planowane-w-ramach-projektu,14215.htm (dostęp: 12.01.2020). 
czyli tzw. Dziewięciu Godnych, najznamienitszych i najodważniejszych kobiet różnych wieków i narodów3 .

Europejska legenda Pentezylei w wiekach średnich została niejako opracowana na nowo. Przede wszystkim z jej historii zniknął Achilles. Na ilustracjach heroina przedstawiana była jako średniowieczna królowa-wojowniczka. Następnie postać ta zapisała się w tradycji jako niewiasta, która wkroczyła w wojnę trojańską z powodu swojej czci dla Hektora. Mit wojny trojańskiej był znany w średniowiecznej kulturze łacińskiej, jednak już nie za sprawą Homera, ale pism dawnych poetów-łacinników ${ }^{4}$. Odseparowanie historii spod Troi od pierwotnej wersji Homerowskiej spowodowało, że ta opowieść poniekąd narodziła się na nowo, przejawiając się również w innych gatunkach literackich. Pentezylea pojawiła się w poemacie Le Roman de Troie (1160)5, napisanym przez dwunastowiecznego francuskiego poetę Benoît de Sainte-Maure. Julian Krzyżanowski wyjaśnia, że utwór powstał w efekcie połączenia dwóch dzieł łacińskich, mianowicie: De excidio Troiae Daresa Frygijczyka oraz Ephemeris belli Troiani Diktysa Kreteńczyka. Francuski truwer nadał temu romansowi zupełnie nowy charakter, zbliżając go do światopoglądu i rzeczywistości czytelnika wieków średnich, zamieniając np. trojańskich wojowników na średniowiecznych rycerzy (Krzyżanowski, 1926, s. 96-98). Temat trojański pojawiał się także w literaturze polskiego renesansu. Marcin Bielski, korzystając ze wszystkich dostępnych sobie źródeł, takich jak teksty: Daresa, Diktysa, Diodora, Owidiusza czy Wergiliusza, przedstawił historię trojańską w jednym z rozdziałów swojej Kroniki świata (Mańkowski, 1962, s. 358). Spolonizowaną wersję antycznych motywów trojańskich można odnaleźć też w polskiej prozie XVI wieku. Anonimowy autor, podobnie jak Benoît de Sainte-Maure, połączył lekturę Daresa i Diktysa, tworząc własny polski przekład zatytułowany Historia o zburzeniu miasta trojańskiego. Jednakże wiedzę o tych opowieściach Polak czerpał z trzynastowiecznej $\mathrm{Hi}$ storia destructionis Troiae Guidona z Colonny - przeróbki Le Roman de Troie. Tekst Guidona był o wiele bardziej rozpowszechniony w Europie, stanowiąc aż do XVI wieku główne źródło informacji na temat wydarzeń spod Troi. Dla ówczesnych czytelników istotna była przede wszystkim wiarygodność tego dzieła - jego zgodność z zasadami moralności oraz realności, które gwarantowały prawdziwość opowiadanej historii (Mańkowski, 1962, s. 141). Z kolei w późnośredniowiecznej Europie motyw królowej Amazonek został spopularyzowany najpierw przez Christine de Pizan w jej utworze Le Livre de la Cité des Dames (1405), zaś piętnaście lat później przez angielskiego mnicha i poetę Johna Lydgate’a of Bury w poemacie Troy Book (1420). Oboje twórców przedstawiło Pentezyleę i Hektora

3 Pozostałe „Osiem Godnych” to: Deiphille, Synoppe, Hippolyte, Menalyppe, Semiramis, Lampetho, Thamarys, Teuta. Lista „Dziewięciu Godnych” pochodzi z końca XIV w. Thomas III Saluzzo wymienił owe heroiny w swoim dziele $L e$ chevalier errant, por. https://www.heraldica.org/topics/worthies.htm [dostęp: 12.01.2020].

4 Wprowadzenie w tematykę mitu wojny trojańskiej w literaturze średniowiecznej opracował Jerzy Mańkowski w swoim studium: Mańkowski, 1962.

5 Utwór Le Roman de Troie miał duży wpływ na dzieła wielu zachodnich twórców, w tym Geoffreya Chaucera

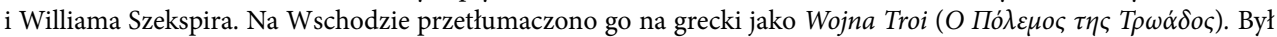
to zdecydowanie najdłuższy średniowieczny romans grecki. Por. https://en.wikipedia.org/wiki/Roman_de_Troie [dostęp: 12.01.2020]. 
jako kochanków. Według opowieści Lydgate’a Amazonka przybyła do Troi, ponieważ zakochała się w cnotliwym rycerzu Hektorze. Para została ukazana jako personifikacja ideałów rycerskich, czego dowodzi obraz Pentezylei klęczącej przed zwłokami Hektora, obiecującej pomścić jego śmierć. Z dalszego „odwrócenia” przebiegu wydarzeń w średniowiecznej interpretacji wynika, że stojąca na czele armii trojańskiej heroina zabiła wielu greckich żołnierzy, jednak ostatecznie sama poniosła śmierć nie z rąk Achillesa, lecz jego syna. Zgodnie z tą legendą jej ciało zostało pochowane nad Thermodonem, rzeką, u brzegów której żyły Amazonki. Tam zaś liczne świątynie i miejsca kultu potwierdzały heroiczny status kobiety jako średniowiecznej królowej Amazonek (Mayor, 2014, s. 302). Postać Pentezylei ewoluowała w kierunku wizerunku rycerskiej bohaterki w zmodyfikowanym temacie trojańskim, stając się częścią średniowiecznej, romańskiej myśli nawiązującej do antyku (Mayor, 2014, s. 302).

Pentesilea miała być dramatem wyjątkowym. Tragedia została złożona w darze Tomaszowi Zamojskiemu, który po powrocie z zagranicy otrzymał godność wojewody podolskiego ${ }^{6}$. Najnowsze badania nad utworem Szymonowica dowodzą, że tworząc historię królowej Amazonek, autor inspirował się kilkoma źródłami. Wbrew pozorom, mimo wątku wojny trojańskiej, linii fabularnej dramatu nie wyznaczała Iliada, zwłaszcza że sam Homer wspomina Amazonki jako przeciwniczki króla Priama, stąd też w konsekwencji postać Pentezylei jest w tym utworze pominięta. Jak wyjaśnia Ewa Jolanta Głębicka:

O jej udziale w wojnie trojańskiej i śmierci z rąk Achillesa przeczytać natomiast można m.in. w Eneidzie, scholiach do Homera i Wergiliusza, u antycznych mitografów, a nawet historyków. Najpełniejsze jednak przedstawienie tego mitu mógł Szymonowic znaleźć w Ephemeris belli Troiani Diktysa z Krety, a zwłaszcza w pierwszej księdze Tà meth'Hómeron (Wydarzenia pohomeryckie; łac. Posthomerica) Kwintusa ze Smyrny, pisarza z IV wieku. Właśnie ten ostatni utwór był dla polskiego poety głównym źródłem przy tworzeniu dramatu Penthesilea, stąd zaczerpnął główne rysy charakteru tytułowej bohaterki oraz kilka epizodów (Głębicka, 2001a, s. 10).

Szymonowic, tytułując swoją tragedię imieniem głównej bohaterki, poszedł za przykładem dzieła Smyrneńczyka. W zamierzeniu dramat miał uzupełniać lukę narracyjną między Iliada a Odyseją, dla których spoiwem był jeden z epizodów wojny trojańskiej, co jest tradycją późniejszą. Autor Sielanek, podobnie jak Kwintus, w części traktującej o walce Amazonek wyznaczył ramy wydarzeń: poczynając od śmierci Hektora, a kończąc na upadku Ilionu. Losy heroiny przedstawione przez Smyrneńczyka nie stanowią głównej osi tematycznej poematu. Historia królowej Amazonek rozgrywa się na pierwszych jego stronach. Narracja w utworze Kwintusa rozpoczyna się w chwili, w której kończy się Iliada, z kolei losy Amazonki obejmują całą pierwszą księgę poematu. Po śmierci Hektora pogrążona w ogniu Troja przeżywa swoją stratę, jednak Priam już oczekuje przybycia dzielnych Amazonek. Opowieść o heroinie rozpoczyna się wraz z jej przybyciem pod bramy Troi. Księgę tę zamyka opis burzy

\footnotetext{
6 Zbieg wydarzeń w środowisku poety i aktualne podówczas okoliczności jego życia skłaniają ku tezie Ewy Głębickiej, która twierdzi, że ofiarowanie utworu dawnemu wychowankowi mogło być ostatnim pouczeniem w kwestiach militarnych przed objęciem stanowiska przez magnata. Ponadto istnieją przesłanki, że dramat był też pisany z myślą o szkolnym teatrze przy Akademii Zamojskiej (Głębicka, 2001b, s. 154-155).
} 
morskiej, która przegnała okręty zwycięskich Achajów (Bogumił, 2007, s. 149). Ta część utworu skoncentrowana jest głównie na narracyjnym przedstawieniu scen batalistycznych, czemu sprzyjają kryteria gatunkowe właściwe poematowi epickiemu. W Posthomerica po przegranej Trojan jeszcze wiele się dzieje. Z kolei wydarzenia tragedii Szymonowica spleciono opisem przybycia pod Troję Amazonek właśnie pod wodzą Pentezylei, która w walce ponosi śmierć $\mathrm{z}$ rąk Achillesa. I od tego momentu bohaterka obecna jest w tekście tylko w wypowiedziach i rozmowach innych osób. Poeta-łacinnik, zgodnie z regułami dramatu klasycznego, wykłada sceny batalistyczne, wprowadzając rhesis angeliké. Izabela Bogumił objaśnia, że miało to służyć zachowaniu opisu dwufazowego przebiegu walki - wskazać najpierw początkowe sukcesy, a następnie porażkę Trojan. W tym celu do akcji dramatu wprowadzeni zostają posłańcy, którzy zdają relację z pola bitwy, podobnie jak w Siedmiu przeciw Tebom Ajschylosa czy w Fenicjankach Eurypidesa (Bogumił, 2007, s. 155). Ograniczając przedstawienie wydarzeń do historii samej Amazonki, poeta przekształca poemat mitograficzny w tragedię stylizowaną na wzór starożytny. Dramaty grecki i rzymski były doskonale znane autorowi Sielanek, stąd też Szymonowic buduje akcję na podstawie ich strukturalnych właściwości. Przy zachowaniu antycznej zasady trzech jedności nadaje bohaterce epickiej jaskrawsze cechy protagonistki. Zarówno główna akcja, jak i rozmowy, przekazy, sen, wspomnienia - wszystkie te elementy koncentrują się wokół tytułowej protagonistki. Zamojski poeta sytuuje wydarzenia na terenie Troi, ograniczając akcję do jednego dnia. To, co dzieje się poza tą przestrzenią, jest relacjonowane przez posłańców. Tym sposobem losy bohaterki, mimo jej śmierci, pozostają głównym tematem utworu. Wiadomość o sukcesie przynosi pierwszy z posłańców, a o porażce - drugi z nich. Wydarzenia rozpoczynają się wraz ze wschodem słońca, a kończą zgodnie z Arystotelesowską regułą „jednego obiegu słońca” (Bogumił, 2007, s. 154).

Dość skomplikowany schemat związków intertekstualnych pomiędzy Iliadą, Posthomerykami i właśnie dramatem zamojskiego poety sytuuje tragedię Szymonowica pośród międzytekstowych zależności, które można rozpatrywać wedle koncepcji Gérarda Genette’a (zob. Genette, 1979, s. 269-307). Po pierwsze, na poziomie genologii mamy do czynienia z archetekstem, który lokuje Pentesilea w gatunku tragedii dzięki nawiązaniom do treści Iliady, w tym wypadku mitu wojny trojańskiej. Po wtóre, korelacje między utworami widać także w stylistyce, gdy poeta stara się odwzorować styl poprzednika (daje się to zauważyć zwłaszcza u Kwintusa). I oto na samym końcu tego pasma zależności polski poeta przedstawia dramat zatytułowany Pentesilea. Zatem tragedia królowej Amazonek jest ostatnim ogniwem w łańcuchu związków międzytekstowych zawartych w dziełach w wyznaczonej kolejności: Iliada - Posthomerica - Pentesilea. Zamojski poeta w większej mierze inspirował się poematem Smyrneńczyka, a zwłaszcza jego pierwszą księgą, niż samą Iliadą Homera, w której - jak już wspomniano - Amazonki w ogóle się nie pojawiają. Jednakże w wielu ustępach dramatu Szymonowica można dopatrzeć się korelacji z innymi klasycznymi dziełami, w tym z Trojankami Seneki, których wpływ jest widoczny np. w rozmowie 
Andromachy z piastunką (o czym dokładnie w dalszej części). Tragedia Szymonowica była jednocześnie jedynym powstałym w Polsce dramatem, który przedstawia losy królowej Amazonek7.

Kompozycja utworu Simonidesa odpowiada kryteriom dramatu klasycznego, podobnie jak Castus Joseph. Na budowę Pentesilea składają się: prolog, parodos, cztery epejsodia, cztery stasimony i exodos. Jednak poza ogólnym schematem kompozycja, konstrukcja i sposób prowadzenia postaci w obu dramatach różnią się od siebie. W Pentesilea poeta nie wprowadza do charakterystyk bohaterów odwołań do innych dzieł, tak jak czynił to w swoim wcześniejszym łacińskim utworze (Abramowska, 1974, s. 118-122). Zaczerpniętą z Biblii treść dramatu o cnotliwym Józefie autor połączył z pokrewnym tematycznie podaniem helleńskim znanym z Hippolytosa uwieńczonego Eurypidesa (Chmielowski, 1914, s. 19). Zamysł przetransponowania historii narracyjnej na dramat klasyczny stwarzał wiele ograniczeń Szymonowicowi. Dlatego zastosowane przez niego rozwiązania w zakresie koncepcji budowania dialogów, monologów, rysu postaci czy samej konstrukcji utworu budziły skrajne opinie badaczy. Korneli J. Heck ponad sto lat temu pisał, że w przypadku Pentesilea Simonides nie wprowadził rozwiązań typowych dla tragedii antycznej, tak jak w dramacie o Józefie. Pentesilea była postrzegana jako przede wszystkim tragedia źle skonstruowana. Widać to w zaburzonej akcji i we wprowadzaniu co rusz nowych postaci, które nie mają udziału w przebiegu zdarzeń składających się na całą historię (Heck, 1903, s. 309). Ten, niedopracowany według Hecka, pomysł został inaczej przeanalizowany przez badaczy współczesnych. W przeciwieństwie do deskrypcji scen wojennych u Kwintusa konstruowanie akcji w dramacie nie mogło koncentrować się na opisie postępów militarnych Amazonek, ponieważ nie ma tu na to miejsca. Stąd też mylnie w dawnych badaniach nad tragedią Pentezylei częstokroć stawiano tezę, że akcja jest statyczna i pozbawiona dynamiki, właśnie $\mathrm{z}$ uwagi na nagromadzenie oracji i opinii konkretnych postaci na temat zasadności pojawienia się Amazonek oraz toczenia bitwy z Achajami. To, oczywiście, błędny wniosek z uwagi na wymogi formalne dramatu.

Szymonowic nie gloryfikuje bohaterskich postaw wojowników, a czytelne w konkluzji utworu potępienie wojny nie idzie $\mathrm{w}$ parze $\mathrm{z}$ opłakiwaniem rozpaczliwej sytuacji bohaterki (Ziomek, 2012, s. 438-439). W tej kwestii wśród badaczy przeważała opinia Tadeusza Sinki, który

\footnotetext{
7 Omawiając sytuację kobiet w dramacie Simonidesa, należy zwrócić uwagę na znaczenie związku Amazonek z ludami sarmackimi. Według najwcześniejszych podań Herodota Sarmaci to lud koczowniczy pochodzenia irańskiego. Najwcześniejsi z nich, nazywani Sauromatami, pochodzili ze związków Amazonek ze Scytami. I to właśnie za sprawą autora Dziejów Amazonki zaczęły być traktowane jako przodkinie Sauromatów, co również potwierdził Hipokrates, dodając, że Sauromaci zamieszkiwali okolice Jeziora Meockiego, a ich kobiety jeździły konno, strzelały z łuku i ciskały włóczniami (Zielińska, 2012, s. 427). Obecność Amazonek w dziełach literackich często przysparza trudności w określeniu ich funkcji w tekście. Można więc postawić pytanie, czy Simonides, pisząc swoją tragedię, sięgał do mitu, czy właśnie do podań o scytyjskich kobietach. Opowieści o ich wędrówkach po Europie Środkowej znane były także w czasach jemu współczesnych. Już na początku XVI wieku za sprawą Traktatu o dwóch Sarmacjach, azjatyckiej i europejskiej Macieja Miechowity utrwalono identyfikację (poprzez recepcję poglądów Eneasza Sylwiusza Piccolominiego) Polski, Litwy i Rusi z krainą Sarmacji. W tamtych czasach Polskę równie chętnie nazywano Sarmacją, co Rzecząpospolitą. Kult dawnego Sarmaty ukształtował polską świadomość narodową. Zgodnie z wiedzą historyczną sarmackie Amazonki walczyły u boku mężów i ojców, za co były traktowane z wielką czcią. Zamojski poeta, który odebrał gruntowne wykształcenie, nie mógł nie znać tych faktów. Zresztą w samym dramacie autor nazywa Pentezyleę Scytyjką (o czym szerzej przy okazji analizy rozmowy Deidamii z Theano). W dramacie Szymonowica nie odnajdujemy jednak zbyt wielu korelacji pomiędzy zastępem Amazonek walczących przeciwko Grekom a koczowniczkami znad Donu.
} 
twierdził, że podczas pisania tragedii o królowej Amazonek: „Poeta zadowolił się opowiadaniami i lamentami, nie troszcząc się zupełnie o akcję" (Sinko, 1935, s. 109). Sądzono również, że charakterystyka postaci jest nadzwyczaj nieudolna (Hahn, 1895, s. 2). Faktycznie, autor wprowadził do swojego dramatu zdecydowanie za dużo bohaterów i nie każdemu z nich zdołał poświęcić należną uwagę, przez co kreacja poszczególnych postaci wydaje się niepełna, a to nasuwa pytania o zasadność takiego zabiegu. Przytoczone opinie badaczy miały wpływ na pogłębienie zainteresowania polskich humanistów twórczością dramatyczną Szymonowica. Jednak utwór Simonidesa zaczął powracać w dyskursie teoretycznoliterackim dopiero w ostatnim dwudziestoleciu.

Już w pierwszej mowie Pentezylea składa deklaracje dotyczące swoich zamiarów oraz podkreśla własną indywidualność. W hasłach heroiny pobrzmiewają zwroty emancypacyjne, chociaż w XVI i XVII wieku temat wyzwolenia kobiet w zasadzie nie istniał, przez co trudno było im powołać do życia społeczność, która walczyłaby o swoje prawa. Na zorganizowaną działalność ruchu feministycznego trzeba było czekać do XIX stulecia (Hannam, 2010, s. 21). Wbrew temu wyłożona explicite skarga Amazonki dotyczy równości między płciami w zakresie ich codziennych obowiązków. Sens życia kobiety nie może być ograniczony do domowych atrybutów w postaci kądzieli. Powinna ona móc uczestniczyć w aktywności kojarzonej z działaniami wojskowymi, przy czym wspomnienie kądzieli jest tutaj symbolem odrzucenia praw zmaskulinizowanego społeczeństwa (Rusnak, 2011, s. 307-308). Deklaracja Pentezylei, podobnie jak konieczność wyłożenia własnego stanowiska w kwestii stereotypowych ról kobiet, musiała być radykalna i wiarygodna. Dla samej Amazonki stanowiła początek samoidentyfikacji „ja”, które w jej odczuciu ujawniło się w zderzeniu z perspektywą wojny. W związku z tym to przede wszystkim Pentezylea powinna uwierzyć w swoje słowa. Jej wiara w szansę na odwrócenie panującego porządku społecznego musiała być niczym niezmącona:

Więc z takim było zdaniem siedzieć przy kądzieli.

Kość boju rzucaj, boju obyczajem, abo

Zgubie, abo też zginąć prawo miecza każe.

Ale wy, towarzystwa mojego jedyna

Cząstko, chodźcie, najmilsze, i radźcie co czynić.

Wielkie niebezpieczeństwa ten tylko poznaje,

Który się uczestnikiem jego społem staje ${ }^{8}$.

(Pentezylea, 1: w. 14-20) ${ }^{9}$

W wystąpieniu Pentezylei daje się zauważyć wiele analogii do mowy bohaterki Kwintusa. Jednakże jej argumentacja skupia się głównie na przedstawieniu nierówności między statusem kobiety i mężczyzny. Natomiast heroina z poematu Posthomerica nie snuje takich wywodów i przede wszystkim jest skoncentrowana na planach wojennych. Bohaterka w deklaracji daje upust swoim wygórowanym ambicjom. Owszem, szanuje wysoki status przywódców greckich,

8 Cytaty przytoczono według starodruku Ksawerego Zubowskiego, por. Szymonowic, 1778.

9 Powołując się na edycję Zubowskiego, po wskazaniu osoby dramatu podaję numer strony oraz cytowane wersy. 
jednak zawczasu nie uzna swojej klęski za sprawiedliwą, stąd też jej słowa, chociaż motywowane heroicznym celem, są pełne pogardy:

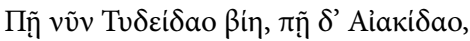

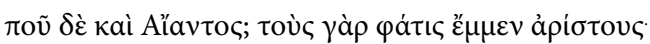
à $\lambda \lambda^{\prime}$ '

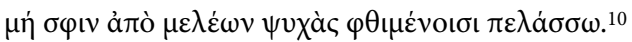

(Q.S. 1.331-334)

Gdzie jest teraz moc Tydeidy [Diomedesa], gdzie Ajakidy [Achillesa], gdzie Ajasa? O nich przecież mówicie, że są najznakomitsi.

Ale ze mną nie odważyliby się stanąć do walki, żebym nie posłała dusz nieszczęśników do [świata] zmarłych.

Sytuacja kobiet w utworze Simonidesa dosadniej pokazana jest w monologach i dialogach aniżeli w samej akcji. Owszem, Pentezylea idzie w bój, ponosi śmierć, do walki rwą się także Trojanki, które zdają się poruszone odwagą Amazonek, jednak zachowanie kobiety jest pełne niekonsekwencji. Pewność siebie Pentezylei słabnie, jeszcze zanim bohaterka chwyta za oręż. Odczuwa wątpliwości, nie wiedząc, czy to ze strachu, czy też z męstwa. W scenie pierwszej czytamy zatem:

Ciebie, Wielki Gradywie, z którego krwie idę,

Wzywam naprzód, ażebyś mię siłą pokrzepił

Niezwyciężoną twoją i godną takiego

Ojca córkę przed światem potwierdził. Lecz czy mię

Błąd zwodzi? A toż znaki, zda mi się, bojaźni

Po mnie się ukazują i coś niedobrego

Wieszczą, czy też, przeciwnie, dzielności początki

Przyszłej są takie, aby od troskliwej trwogi

Pierwszą moc nabierała! Ej, nie ustawaj, mój

Umyśle, ni się łamać złą wróżką dopuszczaj.

Co los stanowi, nie jest w ręku twoich. W twoich

Zaś czynić odważnie, by dobrze, nie radząc się

Bogów, śmierci się chroni<ć>, której bronią szukasz? -

Więc z takim było zdaniem siedzieć przy kądzieli.

(Pentezylea, 1: w. 1-15)

Mimo wygłaszanych haseł nawołujących kobiety do odrzucenia ograniczających je rekwizytów Amazonka nie zabiega o uwagę swoich odbiorczyń. Choć zwraca się do ogółu niewiast jako wszystkich przedstawicielek swojej płci, nie wchodzi w interakcje z kobietami zgromadzonymi wokół

10 Cytaty z poematu Posthomerica za wydaniem: Quintus Smyrnaeus, 1913. Tłumaczenia Autorki. Korekta tłumaczeń - redakcja. 
trojańskiego dworu. Nie wydaje się zainteresowana opinią żadnej z nich, poza swoimi towarzyszkami. Pentezylea chce być postrzegana jako skupiona na swym celu, dlatego uczestniczy jedynie w polityczno-wojskowych debatach. Fakt, po czyjej stronie walczy, nie jest tak ważny, jak sam rezultat tego starcia. Chce być podziwiana, chce być tą, której zawdzięcza się triumf. Kobieta przejawia ogromne ambicje w kwestii precedensowej: manifestacji kobiecej siły nad mężczyznami.

Osobliwie układają się koleje tej walki. Wątpliwości Pentezylei, o których czytamy w jej monologu, powracają w kolejnych partiach utworu. Lęk Amazonki pogłębia się, choć nie zdradza go otoczeniu. Bohaterka stara się kontrolować swoją bojaźń, ale mimo to ciągle obstaje przy własnych zamierzeniach, siląc się na zuchwałość i przejaskrawioną wręcz pewność siebie, o czym czytamy w scenie jej rozmowy z towarzyszkami. Gotowa do boju Amazonka pyta swoje kompanki, czy ma odpierać Greków, będąc na czele wojska, czy stanąć do pojedynku z Achillesem (Pentezylea, 2: w. 15-21). Mimo ogromnej chęci bezpośredniego starcia z najdzielniejszym z Greków na początku lojalnie słucha rad swoich podopiecznych i wybiera walkę w grupie, jej obowiązkiem jest bowiem poddać się rozkazom naczelnego wodza - Priama. Dodatkowym bodźcem, który przez jakiś czas powstrzymywał Pentezyleę przed podjęciem decyzji o konfrontacji z herosem, był sen, w którym pewien wojownik nieustępliwie ją atakuje (Pentezylea, 4: w. 4-14). Zamojski poeta rezygnuje z konstrukcji snu zwodniczego na rzecz snu złowróżbnego, właściwego tragedii. Izabela Bogumił wyjaśnia, że u Kwintusa sen zwodził Pentezyleę i mobilizował do walki, w efekcie której Amazonka zginęła, tak jak chciała tego Pallas Atena. Natomiast w tragedii Simonidesa sen wróżebny ma pełnić funkcję ostrzegawczą (Bogumił, 2007, s. 182). Losy polskiej Pentezylei jeszcze nie są przesądzone. Amazonka ma czas na refleksje, na zmianę decyzji. Jej wybór udowadnia jednak, że nie korzysta ona z tej „sennej szansy”, zagłusza wątpliwości, zmierzając wprost ku śmierci. Autor Sielanek zaczerpnął motyw snu Pentezylei od Smyrneńczyka, jednak dodał do tej części utworu element przepowiedni zagrożenia życia, którego w tekście Kwintusa brak. W dziele Szymonowica z kolei nie pojawia się wzmianka o bogu wojny Aresie, który jako ojciec Amazonki miał we śnie nakłonić ją do walki z Achillesem. Heroina z poematu Posthomerica ma pełną świadomość swojego „nie-śmiertelnego” pochodzenia:

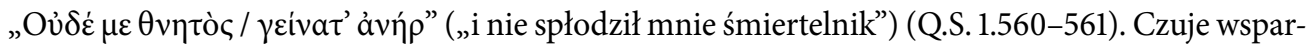
cie ojca, co traktuje jako atut, wyróżniający ją w każdej sytuacji bojowej. Zdecydowanie broni swojego prawa do bycia na polu bitwy, stając w szranki z największymi mistrzami sztuki wojennej. Z kolei Pentezylea polskiego poety toczy najpierw wewnętrzny bój z samą sobą, zastanawiając się, czy w ogóle walczyć po stronie Trojan. W rezultacie kobieta ulega groźbie nierównej walki i najpierw rusza ze swoją falangą (Pentezylea, 4: w. 1-5). W obu dziełach zmagania królowej Amazonek kończą się podobnie, różnią się jednak sposobem ich przedstawienia. Smyrneńczyk wyraźnie zaznacza, że Amazonka odnosi sukcesy, zabijając wielu Achajów. Achilles po jej śmierci odkrywa jej urodę i żałuje, że niewiasta poświęciła swoją kobiecość, wybierając drogę wojny (Łukaszewicz-Chantry, 2014, s. 178). Z kolei postawa Pentezylei z łacińskiej tragedii zostaje zdominowana przez surową ocenę jej działań. Po klęsce nikt nie pamięta odwagi kobiety.

Opuszczenie w tekście wątku wskazującego na obecność boga wojny wynika ze zmiany koncepcji ludzkiego losu. Szymonowic konstruuje zdarzenia tragedii wokół postaci mitologicznych, jednakże nie wprowadza do niej istot sterujących ludzkim przeznaczeniem, kierując się przekonaniem, że człowiek nie jest marionetką losu, sam decyduje o swoim życiu i ponosi 
świadome konsekwencje swoich czynów (Głębicka, 2001b, s. 151). Brak tu fatum, wyroczni, osoby boskiej w tragedii - to istotne odstępstwa od reguł dramatu antycznego.

Poeta grecki nie wspomina o tym, że Amazonki odwodzą Pentezyleę od jej pierwotnego zamiaru stoczenia pojedynku z Achillesem. Wojowniczka Kwintusa to kobieta o wiele bardziej konsekwentna i zdeterminowana. Jest przekonana o swojej sile i wyższości, już nie tylko nad mężczyzna-

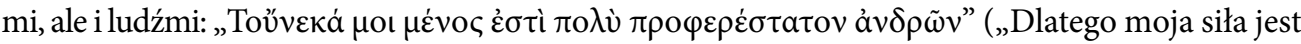
znacznie doskonalsza od męskiej”) (Penthesilea: Q.S. 1.562). Nie ulega chwilowym obawom, nie okazuje ich, nie zdradza sceptycyzmu. Z kolei Amazonka Szymonowica skrywa wewnętrzne wątpliwości, które ujawniają się już na samym początku dramatu, w jej przepełnionym lękiem monologu. Bohaterka jednak szybko przywołuje się do porządku i sama siebie przekonuje o swoich niezmierzonych możliwościach. W prologu obserwujemy więc prezentację antycznej protagonistki, dzielnej virago, która chce odwrócić losy kobiet (Łukaszewicz-Chantry, 2014, s. 182). Cel dokonanej przez zamojskiego poetę modyfikacji tej części historii łączy się z puentą utworu, w której niewątpliwie pobrzmiewa przekonanie autora o tym, że kobiety najwyraźniej nie czują się pewnie w tym, co od wieków przeznaczone było mężczyznom. Innymi słowy, autor Sielanek podał w wątpliwość determinację Pentezylei, ukazując ją jako kobietę, która rozważa złorzeczenia mar sennych. Amazonka dowodnie potwierdza to swoją nieco rozbudowaną tyradą na temat snów, jakby pragnęła odwlec decydujący moment, nakierowując swoje ukryte obawy na resztę współtowarzyszek po to, aby zawczasu usprawiedliwić się z przeczuwanej porażki. Dla porównania - w dziele Kwintusa nie mamy nawet drobnej wzmianki o wahaniu się heroiny lub o jakichkolwiek momentach rozważania innej opcji. Poczucie odpowiedzialności jest w Posthomerykach całkowite i głęboko uświadomione.

Stosunek Trojan do Pentezylei jest bardzo entuzjastyczny, jej przybycie napawa mieszkańców miasta nadzieją. Chór składający się z dziewic trojańskich odśpiewuje pieśni o jej odwadze i szlachetności, które mają przynieść im zwycięstwo:

Obfitości,

Tyś radości,

I starania, jedyna

Ziemianów jest przyczyna.

[...]

Kładąc obie,

Swej na tobie,

Losy fortuny, czyli

Ta się kiedy umili

I wiatry łaskawemi

Ugłaskiwa swojemi.

(Chór, 6. I: w. 1-4, 9-14)

Dopiero w drugiej scenie, po serdecznym powitaniu przez Priama i w poczuciu obowiązku oraz wiary w niej pokładanej, Pentezylea namawia króla, aby pozwolił jej stanąć samotnie do boju (Pentezylea, 10: w. 12-16). Fakt, że Priam przyjął grupę Amazonek z wielkimi honorami, 
skądinąd włączając ich plemię do swoich sojuszników, był wystarczającym sygnałem dla bohaterki, że przełamanie wojennego patriarchatu jest możliwe. Pentezylea chce być traktowana jak mężczyzna, pragnie zająć w szeregu miejsce Hektora. Przyznaje, że woli być dla króla przyjacielem lub synem, a nie córką - wbrew temu jak nazywa ją naczelny wódz:

O Dziewico! Mam za to, że mi ta siwizna

I twój jeszcze kwitnący wiek pozwoli nazwać

Imieniem cię najmilszej córki, chociaj godnaś

Jest wszelkich najpierwszych i czci, i tytułów, [...]

(Priam, 10: w. 21-24).

Kwestia wyglądu Pentezylei nie została w dziele Szymonowica przedstawiona tak szczegółowo jak w utworze Kwintusa, ale tu też Amazonka podobnymi deklaracjami wyrzeka się atrybutów urody i uznania dla jej atrakcyjności. Nie chce być postrzegana przez pryzmat kobiecej fizjonomii, gdyż uważa ją za swoją słabość. Dla porównania - deskrypcje wyglądu Amazonki

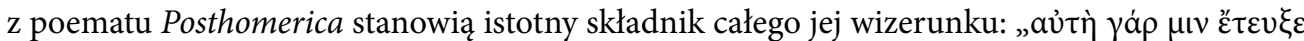

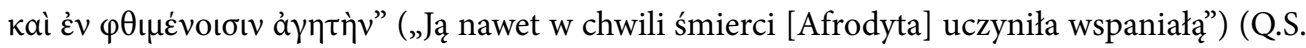
1.666). Grecki poeta świadomie przekuł wdzięk i powab heroiny w atut, nadając im funkcję cech boskich, które przetrwały $\mathrm{z}$ bohaterką nawet po jej śmierci.

Drugi epejsodion tragedii Simonides poświęcił rozbudowanemu wątkowi kobiecemu. Oto mamy scenę, w której Andromacha cierpi po śmierci męża. Użala się nad swoim losem, jedynie w synu Astyanaksie widzi pocieszenie i liczy na to, że pomści on krew ojca. Sama jednak wie, że to jej obowiązkiem jest wychować go oraz przygotować mentalnie do roli następcy (Andromacha, 17: w. 10-22). Andromacha po części reprezentuje wzorzec matki wychowawczyni, charakterystyczny dla kobiet czerpiących ze wzoru macierzyństwa Matki Bożej Wychowawczyni, powierzających swój los jako matek w ręce opatrzności Bożej. Szymonowic wprowadza tu zaszyfrowany obraz chrześcijańskiej kultury, gdyż explicite sfera metafizyczna w utworze jawi się w postaci świątyni Pallady. Andromacha nie wyjdzie poza swoje funkcje i wyuczone zachowania. Postępuje tak, jak postąpiłaby większość kobiet w tych okolicznościach. Część utworu z lamentem wdowy po Hektorze jest uważana za jeden z nielicznych momentów tej - jak twierdzi Sinko - nieudanej tragedii, gdzie objawia się liryczny talent Szymonowica (Sinko, 1935, s. 109). Zresztą teza o tym, że to właśnie poszczególne fragmenty liryczne dramatu stanowią jej największą wartość, została później powtórzona przez Jerzego Ziomka (Ziomek, 2012, s. 439).

Szymonowic wykorzystuje pomysł Kwintusa, który wprowadził do poematu osobę Andromachy za pomocą formuły epickiego monologu. Jednak autor Sielanek, właściwym klasycznemu dramatowi zwyczajem, konstruuje dialog, w którym bohaterka mogłaby wyrazić swoje myśli. Dialog oczywiście wymaga obecności interlokutora, stąd swoje miejsce w scenie, a także w ogóle w sferze kobiecych spostrzeżeń na temat walki Amazonek pod Troją, zajmuje mamka Astyanaksa. Scena rozmowy Andromachy z piastunką nawiązuje do tradycji antycznego dialogu dramatycznego typu domina-nutrix (Bogumił, 2007, s. 162). Jest to rozwiązanie, które stosowano w celu przytoczenia ekspresyjnej dyskusji toczonej między dwójką bohaterów o przeciwstawnych poglądach. Prekursorem tej techniki był Seneka, który wykorzystywał ją z przynależnym 
sobie mistrzostwem, prezentując nierzadko retoryczne figury wyolbrzymiające opozycyjne stanowiska niemalże do kłótni. Dialog typu domina-nutrix miał zdynamizować bieg zdarzeń, doprowadzając do podjęcia kluczowych decyzji. Jednakże w utworze Simonidesa rozmowa ta nie toczy się w tak żywym tempie, przez co nie spełnia tej ostatecznej funkcji, jakby po to, aby dać wyraz przekonaniu, że kobiece opinie (nawet te najbardziej skrajne i odważne) nie mogą być zaczynem istotnych wydarzeń.

Samo wprowadzenie postaci piastunki do dramatu Pentesilea to zabieg typowy dla dramatu klasycznego. Nianie towarzyszą głównym bohaterkom Medei, Fedry, gdzie zapowiadają wejście tytułowych heroin na scenę (Rusnak, 2008, s. 43). W polskim dramacie piastunkę - Panią Starą - spotykamy w Odprawie posłów greckich Jana Kochanowskiego, gdzie również wykorzystano motyw trojański. Udział niani w tragedii Szymonowica nie różni się niczym od typowego schematu. Jest ona spokojną, cichą towarzyszką, która kołysanką próbuje ukoić płacz malca. Słysząc tę pieśń, Andromacha wpada w jeszcze większą rozpacz, nie widzi już bowiem żadnego ratunku dla Troi (Andromacha, 19: w. 20-28). Jednakże pełna nadziei opiekunka pociesza ją, że oto przybyła mężna królowa Amazonek i z pewnością ocali Trojan, których losy nie są jeszcze przesądzone (Mamka, w. 571-617) ${ }^{11}$. Wdowa wątpi w siłę kobiety, obstając przy wierze w możliwości mężczyzn na polu walki (Andromacha, 22: w. 23-24). Andromacha nawet w nieco obraźliwy sposób przywołuje obraz Amazonki, zarzucając jej płonne obietnice. Mówi o tym, jak w czasie uczty Pentezylea odurzyła się winem, po czym odgrażała się, że pokona włócznią Achillesa (Bogumił, 2007, s. 162). Zuchwała heroina już wtedy była pewna, że najważniejsza część walk będzie toczyć się między nią a herosem.

Dosyć się nasłuchałam próżnych tych obietnic

Oto i wczoraj siedząc przy królewskim stole,

Głowę winem zagrzawszy, wiele naznosiła

I naw nieprzyjacielskich, i ludu zbrojnego.

A samego ich króla trzykroć mieczem płytkim

Zraniwszy, zgroziła się po wszystkich ulicach

Miasta pewnie powłóczyć końmi zhańbionego.

(Andromacha, 21: w. 31-34; 22: 1-4)

Opinie mamki i królowej zderzają się ze sobą na poziomie dialogu domina-nutrix. Z jednej strony wyraża je pełna optymizmu Mamka, a z drugiej - pogrążona w żałobie oraz złych przeczuciach Andromacha. Kobieta o niskim statusie społecznym, której dotychczasową rolą było opiekowanie się szlachetnie urodzonym potomkiem, pragnie społecznych zmian. Naprzeciw niej staje żona wielkiego wodza, która woli odwracać wzrok od tego, co ma się wydarzyć. Dyskusja kobiet ukazuje dysonans pomiędzy naiwnymi pragnieniami i bezlitosnym realizmem. Andromacha, jak nikt inny, przekonała się o bezwzględności Achillesa, dlatego zdecydowanie stoi po stronie rozsądku, który wynika z naturalnych praw rzeczy, a przywódczynię Amazonek

${ }^{11} \mathrm{~W}$ przekładzie Zubowskiego nie odnajdujemy wypowiedzi Mamki na temat nadziei związanych z przybyciem Amazonki. Tutaj cyt. za: Simonides, 1618 (numeracja stron starodruku jest niepełna). 
uważa za uzurpatorkę (Rusnak, 2011, s. 312-313). W perspektywie przyjętej przez wdowę ukazano Pentezyleę jako egotystkę niepogodzoną z własnymi słabościami.

W tej samej scenie, pod koniec rozmowy Andromachy z Mamką, dołącza Aethra, która przybywa z zaproszeniem od Heleny, by wraz z innymi synowymi Priama obserwować przebieg walk $\mathrm{z}$ wieży (Aethra, 22: w. 1-7). Królowa odmawia, nie chcąc dłużej patrzeć na śmierć. Sama czuje się umarła pośród żywych. Woli tradycyjnym zwyczajem dołączyć do niewiast, które wybierają się do świątyni Pallady z haftowaną szatą (Andromacha, 23: w. 1-6). Aethra (spolszczona jako Ajthra) nie jest jednak zwykłą służącą. To matka Tezeusza, który wykradł dwunastoletnią wówczas Helenę, ale ze względu na jej wiek nie poślubił jej. Ajthra opiekowała się spartańską księżniczką, jednakże Dioskurowie uwolnili siostrę, a jej opiekunkę wzięli do niewoli (Graves, 1974, s. 336). Później, gdy Helena uciekła z Parysem, zabrała ze sobą Ajthrę, którą ciągle poniżała. Kobieta była zatem niewolnicą na zamku wroga, a mimo tego jak twierdzą niektóre przekazy - to właśnie ona nakłaniała Helenę do opuszczenia Menelaosa (Głębicka, 2001a, s. 12). Chociaż postać Ajthry pojawia się przelotnie w tragedii Szymonowica, jej obecność należy analizować na podstawie wcześniejszych podań. Kobieta ta w dramacie przyjęła typowo konformistyczną postawę. Trzeba jednak zauważyć, że jest to historia wysoko postawionej kobiety, która została poddaną. Nagle z roli królowej Trojzeny, żony władcy ateńskiego Ajgeusa i matki Tezeusza, zmuszona była wejść w rolę służki, dopasowując się do obcych jej warunków panujących na terenie wroga. Toteż w Pentesilea została przedstawiona jako kobieta uległa, wykonująca swoje obowiązki i pogodzona ze swoim losem.

W tragedii odnajdujemy wypowiedzi, które odpowiadają wyobrażeniom walki o prawa kobiet. Niektóre z niewiast demonstrują postawę mówiącą, że można odwrócić ład społeczny. Tych głosów jest zdecydowanie mniej niż zwolenniczek tradycyjnego porządku. Stąd też ta jednostkowość stanowi w Pentesilea punkt, który ma przykuwać uwagę. Hasła te, ówcześnie uważane za absurdalne, podnoszone są jednak tylko po to, aby je następnie obalić - poprzez zakończenie dramatu wyrażające ustaloną dawno temu hierarchię. Poeta-łacinnik powtarza schemat interludium z poematu Posthomerica. W dziele Kwintusa uwiedziona przykładem Pentezylei Hippodamia również prezentuje „feministyczne” poglądy i skutecznie zachęca Trojanki do wzięcia udziału w walce. W interludium ta scena to coetus feminarum - zgromadzenie kobiet, które chcą się zintegrować oraz solidarnie walczyć, by zwyciężać lub ginąć wraz z mężami i ojcami (Bogumił, 2007, s. 157). Odpowiednikiem Hippodamii w tekście Szymonowica jest Deidamia. Bohaterka także jest uczestniczką orszaku, który udał się do świątyni Pallady w celu złożenia peplosu. Zgodnie z regułami dramatu klasycznego w tej scenie, obok zebranych kobiet, pojawia się Chór. Motywacja Deidamii nie ma tak pozytywnych konotacji jak w utworze Smyrneńczyka. Poza jasnym przekazem na temat siły kobiet, które pragnie poderwać do walki, albowiem - jak twierdzi - fizycznie i mentalnie nie brakuje im niczego, co wyróżnia mężczyzn, jej drugim celem jest pomsta za uśmiercenie bliskich. W kontekście wątku feministycznego bohaterka zdaje się nawet twierdzić, że płeć nie determinuje umiejętności toczenia wojen. Fakt, że ktoś jest mężczyzną, nie oznacza, że jest godnym wojownikiem - mówi Deidamia: 
Nas wojennych, ale to samo przyznać trzeba

Cieniu kątów i temuż gnuśnemu zamknieniu.

Zdatne chłopy do wojny? Oni wszyscy mocni?

(Deidamia, 32: w. 22-26)

Kobiety, tak samo jak mężczyźni albo nawet bardziej, są zdolne do poświęcenia w walce. Przykładem tego jest mężna Pentezylea, którą wychwala Deidamia:

Bez wątpienia, byśmy się tak ćwiczyły jak ci,

Bylibyśmy tak abo więcej sposobniejsze.

Dość jasny mamy dowód tego, w Amazonce

Naszej, która ozdobą płci jest największą. [...]

(Deidamia, 32: w. 29-32).

W swojej przemowie buntownicza Deidamia próbuje uświadomić współtowarzyszkom ułomny los kobiet, ich wykluczenie z życia publicznego, niemożność podejmowania ważnych decyzji. Mimo ich życiowej mądrości, dojrzałości emocjonalnej, doświadczeń w radzeniu sobie z wieloma trudnościami nie mogą cieszyć się one podziwem i honorem. Odważna niewiasta idzie dalej w swych deklaracjach, głosząc, że kobiety są traktowane gorzej, gdyż każdego dnia skazuje się je na życie w domowym więzieniu. Nie mają więc szansy, aby dowieść, ile są warte:

Stąd to, stąd nasza dola w porównaniu mężczyzn

Gorsza, które jakoby na martwą nieczynność

Skazane, siedzieć musim w sromotnym więzieniu

Ścian domowych, próżne tam ginąć całe życie.

Gdy tymczasem mężowie i Rzeczpospolitą

Rządzą, i wojny zwodzą, i sławy dostają,

Wszędy do niej szeroko mając plac otwarty.

(Deidamia, 32: w. 12-18)

Słowa Deidamii mają na celu zarówno uświadomić kobietom ich wartość, jak i pobudzić je do zemsty. Każda z nich straciła w wojnie kogoś bliskiego. Przemowa niewiasty oddziałuje również na Chór, który popiera pomysł zemsty i ponagla do działania resztę zgromadzonych:

Zgoda, zgoda na wszystko, pospieszma bez zwłoki

Odzyskiwać najmilszych Trojan martwe zwłoki,

Na pomstę Greków, której nie słodziej, pragnienia:

Pragnęż krwi nieprzyjaciół, pragnę nasycenia.

(Chór, 33: w. 25-28)

Niemniej jednak, podobnie jak w przypadku rozmowy Andromachy z Mamką, rozentuzjazmowany tłum powstrzymuje kolejna kobieta domagająca się utrzymania ustalonego porządku. I w tym momencie wypada odwołać się do reakcji kapłanki Theano, która pojawia się w drugiej 
oracji Smyrneńczyka oraz - w odpowiadającej jej - scenie dramatu Szymonowica. Theano w obu przypadkach gasi zapał kobiet, które, przekonane o własnych możliwościach, wracają do swoich obowiązków. Simonides składa dwie kobiece przemowy z poematu Posthomerica w jedną scenę dialogu Deidamii i Theano, która zostaje wkomponowana w dalszą akcję dramatu. Kapłanka w utworze zamojskiego poety także sprzeciwia się podburzaniu niewiast. Wygłasza mowę skierowaną do uczestniczek orszaku. Kobieta nawołuje do spokoju, tłumacząc nieroztropność i lekkomyślność takich działań:

Gdzież wy bez rozumu bieżycie? Zguby chcecie!

[...]

Kto chce być nauczonym, trzeba temu, aby

Spokojny umysł serce wolne miał od żółci,

Żadnemi uprzedzony nie będąc zdaniami.

(Theano, 34: w. 12, 14-16)

Theano zakłada, że bezmyślna chęć naśladowania, wynikająca z kierowania się nagłymi emocjami w sytuacji kryzysowej, zawsze będzie kończyć się śmiercią kobiet, ponieważ ich miejsce jest w domu, a nie na polu walki. Niewiasta, rwąc się do miecza, przyniesie hańbę mężowi, któremu ślubowała wierność i posłuszeństwo. Takim postępowaniem tylko go ośmieszy. Męstwo mężczyzny zostanie zakwestionowane, jego wybranka porzuca bowiem łoże na rzecz innych celów:

Znasz, co mówię, omijam jeszcze to, że męża

Masz, któremuś ślubiła wiarę i powolność,

Nic nie mając bez jego władzy czynić, a też

Dobrze teraz go rzucać i brać dzieło przed się,

Które sromotną hańbę przynieść pewnie może.

A porzucać z pogardą łoża, władzy, wiary.

(Theano, 35: w. 22-27)

Kapłanka zaleca kobietom, by trwały przy kądzieli, a walkę pozostawiły mężom, ponieważ zamiana ról spowodowałaby w państwie chaos. Przytacza argumenty poświadczające istnienie nierówności płci jako odwieczne prawo rządzące światem. Natura wie, co robi - mówi Theano. Między kobietami a mężczyznami istnieje wiele nieusuwalnych różnic fizycznych oraz charakterologicznych, to zaś wpływa na sytuację społeczną obu płci, motywuje ich role życiowe i wynikające $\mathrm{z}$ nich skutki:

Dopiero do was mowę obracam, nic próżno

Nie wydaje natura i nie wylega,

Co by dziką potworą było i czczym dziełem.

(Theano, 35: w. 28-30) 
Postawa kobiet w tragedii Szymonowica jest o wiele bardziej agresywna, niż pokazał to Kwintus. Theano Smyrneńczyka wyraża pesymizm i obawy o losy Troi. Nie popiera podawania Amazonki za wzór innym niewiastom. Ta sama bohaterka łacińskiej tragedii wypowiada się o Pentezylei z odrazą, nazywając ją scytyjską virago, która niesłusznie weszła w rolę kobiety-żołnierki: „Creatur hanc si quis Scytham viraginem” (Theano: k. G 1, w. 22)12. W tym odczytaniu walcząca niewiasta zostaje przedstawiona niemalże jak dziw natury, który pociągnie Troję na dno.

Stosunek Theano do udziału kobiet $\mathrm{w}$ walce wydaje się $\mathrm{w}$ poemacie epickim o wiele łagodniejszy. Wypowiedzi kapłanki mają charakter pozytywny. Widzi nadzieję w zwycięstwie, pod warunkiem, że sprawa zostanie w rękach mężczyzn. Simonides zamienia pesymistyczną orację Hippodamii na pełną ekscytacji wypowiedź Deidamii. Bohaterka Smyrneńczyka przeczuwa klęskę oraz dzień niewoli i na podstawie tej obawy buduje swoją motywacyjną argumentację. Natomiast nastawiona bojowo niewiasta $\mathrm{z}$ utworu Simonidesa jest przekonana o zwycięstwie Trojan (Bogumił, 2007, s. 161). Porównując interludium z poematu Posthomerica do sceny rozmowy Deidamii i Theano z tragedii zamojskiego poety, należy zauważyć, że ogólny cel wypowiedzi kobiet wydaje się identyczny: chodzi o przyspieszenie biegu zdarzeń w walce o Troję. Jednakowoż nawoływania Hippodamii/Deidamii zostają zatrzymane przez Theano, przez co wszelkie zamiary tłumione są w zarodku. Różnica tkwi w odczytaniu tej sceny, które jest odmienne ze względu na kompozycyjne składniki obu gatunków. Umieszczenie oracji w interludium czyni ją jedynie scenką rodzajową, swego rodzaju przerywnikiem, z kolei w tragedii zahamowanie akcji ukazuje dalsze (możliwe) reperkusje dla działań Pentezylei (Bogumił, 2007, s. 157).

Jeśli zaś idzie o samą bohaterkę Szymonowica, trzeba zauważyć, że w dyskusji kobiet pobrzmiewają echa przeszłości. Nie bez powodu „rewolucjonistką” zostaje tu właśnie Deidamia, czyli córka Antymacha. Theano zwraca się do niej: „Puella Antymachia”, a zatem przywołując jej rodowód. Historia powtarza się, co widać w analogii pomiędzy jej przemową do chóru a wcześniejszymi poczynaniami jej ojca, który podburzył Trojan przeciw greckim posłom. W obu opowieściach pojawiają się również osoby, które chcą być głosem rozsądku podczas prowokacji do kolejnego konfliktu: „I tak jak Antenor uratował Menelaosa przed podjudzonym przez Antymacha tłumem, tak jego żona Theano gromi trojańskie kobiety i przywołuje je do porządku" (Głębicka, 2001a, s. 11). Ostatecznie tę polemikę wygrywa Theano, a niewiasty, które otrząsnęły się ze swej „niedorzeczności”, decydują się wrócić do domów (Chór, 38: w. 19-22). Jednakowoż fakt, że dialog między Deidamią a Theano został niemalże czterokrotnie wydłużony w stosunku do poematu Smyrneńczyka, jest argumentem, który świadczy o tym, że należy tę część dramatu odczytywać w kontekście socjologicznym, pytając o granice dla płci i określając miejsce kobiety w świecie.

\footnotetext{
12 Cytat według łacińskiego starodruku: Simonides, 1618 (numeracja stron starodruku jest niepełna). Zubowski w tej samej partii tekstu wykorzystuje wiedzę na temat terytoriów zamieszkiwanych przez Amazonki kaukaskie i w swoim przekładzie nie nazywa jej scytyjską wojowniczką (za poetą-łacinnikiem), lecz Tatarką: „Jeśli mi zaś Tatarską tę, stawicie dziewkę" (Theano, 35: w. 28). Tłumacz mylnie zasugerował się regionem oraz wizerunkiem wojownika tatarskiego jako konnego łucznika. Jeśli przyjąć, że polscy Sarmaci wywodzą się od plemion scytyjskich, z których pochodzą Amazonki, to wskazana przez Zubowskiego Tatarka nie mogła być jedną z wojowniczek dramatu Simonidesa.
} 
Sam przebieg bitwy między Troją a wojskami greckimi wiele mówi o postrzeganiu tytułowej heroiny przez innych bohaterów dramatu. Było to m.in. konsekwencją odpowiedzialności, jaką na siebie wzięła. Chodzi tu o ewoluowanie jej postaci w czasie bitwy. Dla przykładu, jeden z żołnierzy, widząc śmierć swoich towarzyszy broni, przypisuje całą winę nierozwadze i pysze Pentezylei (Żołnierz drugi, 40: w. 27-28). Porażka Trojan pod jej wodzą boleśnie weryfikuje opinie o Amazonce. Uznanie i wielkie nadzieje, z którymi wkroczyła do Troi, zostają zastąpione gorzkimi oskarżeniami. Według relacji posłańca Pentezylei zarzuca się brawurę oraz skłonności do ulegania prowokacjom. Mimo wcześniejszej przewagi bohaterka reaguje emocjonalnie na drwiny Achillesa, traci czujność, wskutek czego porzuca obraną strategię, atakuje herosa, na oślep uderzając w jego tarczę toporem. Achilles wykorzystuje niepewność Amazonki i grotem przebija jej pierś (Poseł, 49: w. 1-2). Kobieta ulega chwili, całkowicie sprzeniewierzając się nakazom Priama. Emocje okazują się jej największą słabością i to odziera Amazonkę z heroizmu, tworząc jej wizerunek rozszalałej „dzikuski”.

Perspektywa zwycięstwa w starciu z Achillesem nie wydawała się Amazonce ważna ze względu na wybawienie Ilionu. Istotą sprawy była chęć udowodnienia sobie, kim naprawdę jest. Na szali tego pojedynku leżała szansa na rozstrzygnięcie dylematów tożsamościowych, które dodatkowo nasiliły się w momencie, kiedy do świadomości bohaterki dotarło, że aby uwierzytelnić potęgę kobiet, nieuniknione byłoby sięgnięcie po męskie atrybuty. Problem polegał na tym, że kobiety nie posiadały również w pełni wypracowanej przez siebie strategii wojennej. Mimo że Amazonki miały doświadczenie w walce, brakowało im przeświadczenia, że są w stanie zapanować nad sytuacją. Jednakowoż to nie przeszkodziło Pentezylei w podjęciu ryzyka. Postawę heroiny doskonale opisuje Radosław Rusnak, który sytuuje Amazonkę w perspektywie Nietzscheańskiej koncepcji nadczłowieka. (Kobieta ta zdawała się mieć obsesję na punkcie bycia podziwianą.) Ponadto Pentezylea, tak jak człowiek Nietzschego, chciała wyróżniać się niezwykłą wolą mocy, a także sprzeciwiała się normom moralnym, które zostały ustanowione przez społeczeństwo (Rusnak, 2011, s. 309). Kobieta pragnęła samotnego triumfu, który uczyniłby z niej bohaterkę dokonującą niemożliwego. Porażka Pentezylei była zarazem jej klęską tożsamościową. To, co tak dumnie sobą reprezentowała, okazało się tylko imaginacją. W związku z tym można umiejscowić tę postać w literackiej i kulturowej tradycji „kobiecego antyideału”. Ze względu na wizerunek, który sobie stworzyła, a także na tę konkretną historię walki pod Troją, heroina bardziej przypomina bohaterki obdarzone „męskim duchem” aniżeli bezwzględne barbarzynki. Szymonowic kilkukrotnie twierdzi, że gwałtowny i destrukcyjny atak Pentezylei na Achillesa jest czynem niemal barbarzyńskim, charakterystycznym dla dzikich scytyjskich Amazonek. Sama bohaterka chce być odbierana jako typowa przedstawicielka tradycji virago, czyli kobiet, które świadomie decydują się na przekroczenie granic wyznaczonych dla ich płci. Viragines opuszczają domostwa, zdecydowane wkroczyć na „męską drogę”, dążą do udziału w życiu publicznym. Z powodu oddalenia od mężczyzn często zmuszone są do przetrwania w sytuacjach kryzysowych, co wymaga od nich ogromnej odwagi (Łukaszewicz-Chantry, 2014, s. 170). Amazonka Simonidesa wydaje się chcieć tego samego. Jednak mimo obrania „męskiej drogi” jej postać nie zalicza się do grona kobiet, którym udało się pokonać mężczyzn. Heroina działa w afekcie, wyróżnia ją taka sama gwałtowność, jaka cechowała Medeę - w szale gniewu spowodowanym zdradą Jazona bohaterka zabiła kobietę, dla której ją porzucił. 
Pentezylea nie ma dostatecznej siły umysłu, która wyróżniała protagonistkę Eurypidesa. Z powodu złowróżbnego snu wiele rozmyśla przed walką, ale nie rezygnuje $\mathrm{z}$ udziału w starciu. Mimo ataku cel, jakim było uśmiercenie Achillesa, pozostaje jednak na poziomie planu, który nie zostaje zrealizowany. Przyczyn tego stanu rzeczy można dopatrywać się w głównej motywacji heroiny, którą była ambicja zdominowania mężczyzn, a nie zemsta, tak jak w przypadku orszaku innych charyzmatycznych i władczych kobiet, takich jak: Medea, Klitajmestra, Fedra czy królowa Saków Zarinaja (zob. Janik, 2017, s. 66). Przykłady te ukazują odmienne podłoże zbrodniczych czynów niewiast, które w kulturze zapisały się jako „antyideały kobiece”. W przeciwieństwie do Pentezylei - której afekt uwidocznił się tylko w momencie ataku na Achillesa, jej początkowe działania były bowiem zamierzone - pozostałymi kobietami kierowały silne i gwałtowne uczucia, w tym zdrada, miłość, desperacka chęć ochrony innych ludzi. Pobudki bohaterki Simonidesa były zbyt powierzchowne, aby uruchomić w niej wszechogarniającą siłę, która doprowadziłaby ją do ostateczności. W konsekwencji czyny Pentezylei nie wzbudziły lęku, a tym samym nie uzewnętrzniły słabości mężczyzn. Heroina została surowo oceniona przez towarzyszy broni właśnie ze względu na bycie „obcą” w tej wojennej sytuacji.

Pentezylea nie była tylko wodzem swoich Amazonek, ale także wojsk trojańskich, jej klęska ma zatem podwójny wymiar. Przyjęła odpowiedzialność za obcą formację, na nieznanym terytorium. Z takimi zobowiązaniami powinna być symbolem wszelkich cnót. Szymonowic jednak posłużył się jej figurą do ukazania antytezy żołnierza. Kogoś, kto reaguje zbyt emocjonalnie, nie potrafi chłodno kalkulować, rozsądnie dysponować siłami oraz wykorzystywać swoich mocnych stron. Najdobitniej świadczą o tym słowa drugiego posłańca, który już na początku składanego Eneaszowi raportu wskazuje, że Amazonka nie starała się utrzymać szyku wojsk ani wykorzystać kluczowych momentów na ofensywę:

\section{ENEASZ:}

Byłoż wojsko szykowne, było uzbrojone?

POS[EE]:

Jaki szyk - ślepo wszystko kazano, czyniono.

Ładu żadnego, głupi rząd, bitwa szalonych.

I to zgubiło.

(Eneasz, 47: w. 5, Poseł, 47: w. 48-50)

Kobiety przedstawione w Pentesilea nie są traktowane zgodnie z prawami, którym podlegają mężczyźni, co już przed ponad stu laty zauważył Piotr Chmielowski: „[...] poeta bynajmniej takich dążności nie pochwalał" (Chmielowski, 1914, s. 290). Pentezylea, wraz ze swoimi hasłami na temat dyskryminacji kobiet, zostaje zdyskredytowana przez własną śmierć, a także w rezultacie niemocy swych towarzyszek. Okazuje się, że wprowadzenie kobiecych postaci do tragedii miało podkreślać konieczność życiowych ról, które są im przeznaczone. Porażka w walce dowodnie świadczy o tym, że niewiasta winna pozostać przy tradycyjnym dla jej płci i wynikającym z dziedzictwa kultury modelu życia. Bez różnicy, czy mowa o Amazonkach, które poniosły klęskę, czy o kilku innych bohaterkach dramatu, w tym o świadomej swego losu jako 
wdowy Andromasze bądź o kapłance Theano, która powstrzymuje Trojanki przed zbrojną aktywnością. Nie ma znaczenia, w jakim miejscu i w jakich okolicznościach żyje kobieta. Jeśli podejmuje decyzję, aby wejść w zakres ról przynależnych mężczyznom, to i tak, prędzej czy później, jej droga walki okaże się bezowocna - każe sądzić Szymonowic. Dom, najbliższa okolica oraz zaciszne wnętrze świątyni zostały przypisane konkretnemu zestawowi codziennych, typowo kobiecych rytuałów: trosce o ognisko domowe, macierzyństwu oraz wypełnianiu obowiązków religijnych (Rusnak, 2011, s. 308). Nie da się ukryć, że nakreślona w tej tragedii perspektywa co do ideału kobiety jest typowo męska. Mężczyźni chcą widzieć niewiasty jako żony podległe mężom. Kobieta ma być świadoma swojego losu i w pełni podporządkowana wszystkiemu, co się z nim wiąże. Zamojski poeta „buduje” postać kobiety jako alegorię żołnierza niezdolnego do walki. Jednakże Pentezylea, chcąc odciąć się od kobiecej służby, wkracza na terytorium rycerskiego etosu, co podkreśla nawoływaniem do armorum labor („rycerskiej pracy”), manifestuje swoje żądania poprzez podkreślanie własnych aspiracji i wygłaszanie opinii o samej sobie (Rusnak, 2011, s. 309). Ostatecznie, te dwa antagonistyczne stanowiska nie zostały w utworze zrównoważone. Szymonowic ewidentnie waloryzuje role kobiet w określony sposób: ukazuje je jako tę część społeczeństwa, która ma powstrzymać się od aktywności. Ich udział w wojnie to jedynie bierne przyglądanie się rozwojowi wydarzeń $\mathrm{z}$ bezpiecznej odległości i pokorne zdanie się na los.

Puenta dramatu przedstawia płeć piękną jako pozbawioną naturalnych predyspozycji do tego, aby dowodzić. Walka nie jest sprawą kobiet, natomiast wypełnianie domowych obowiązków, rodzenie dzieci, dbanie o mężów, a w wolnej chwili przędzenie - już tak. Temu usilnie próbuje zaprzeczyć Pentezylea, przemawiając na początku dramatu. Jej śmierć z rąk Achillesa zostaje przedstawiona w tragedii w taki sposób, który staje się gorzkim potwierdzeniem już i tak zakładanej prawdy.

Sięgnięcie do tematu wojny trojańskiej i ostateczna klęska Pentezylei zdają się jednak rozwiewać wątpliwości co do uznania zamojskiego poety dla jej wojskowej działalności. Można postawić tezę, że tragedia autora Sielanek poprzez postać Pentezylei wyraża lęk przed matriarchatem jako nienaturalnym porządkiem politycznym. Z całą pewnością losy tytułowej Amazonki wpisują się w nastroje typowe dla przeciwników panowania kobiet, mimo tego że w czasach poety niewiasty nie walczyły o dopuszczenie do rządów. Problematyczną kwestią były dyskusje na temat ich dążeń do rozszerzenia zakresu aktywności życiowej, chociaż krytyka tego typu postaw była - w tym okresie, kiedy żył Simonides - o wiele łagodniejsza niż w zachodniej Europie (Kuchowicz, 1990, s. 13). Postać Amazonki Szymonowica łączy się z dyskusją na temat równości płci w XVI i XVII wieku. Był to szczególny czas w ewolucji świadomości społecznej. Wówczas niewiasta zaczęła być postrzegana jako zagrożenie dla powszechnego ładu opartego na patriarchalizmie (Bogucka, 1998, s. 7). Kobiety współczesne Szymonowicowi miały swoją przestrzeń aktywności skupioną wokół spraw domowych (czy to jako pracowite gospodynie, czy jako wytworne damy), co też było głównym argumentem dla wniosku, 
że w okresie staropolskim sytuacja kobiet była dobra, o ile były one podporządkowane swojemu niższemu statusowi ${ }^{13}$.

Simonides stawia Amazonkę w opozycji do bohaterek, których cechy zbliżają je do rodzimego obrazu Polki. Poprzez negację postawy głównej protagonistki dramat Simonidesa prezentuje ideał niewiasty bliższy tradycyjnemu pojmowaniu kwestii kobiecej. Pentezylea Szymonowica nie pasuje do wizerunku polskiej kobiety. To mityczna heroina, która mimo swoich aspiracji ponosi klęskę, podczas gdy Polka nie odważyłaby się na taki czyn. Amazonka Simonidesa nie zostaje „zeswojszczona”, na co dowodnie wskazuje fakt, że nie przejawia żadnych rodzimych cech, takich jak: skromność, pobożność, rozwaga czy subtelność. W ogólnym wymiarze Pentezylea nie jest też przedstawicielką polskiej tradycji sarmackiej. Wręcz przeciwnie. Jest postacią zamierzchłą, niepasującą do rodzimego obyczaju, co w konsekwencji uniemożliwia wprowadzenie jej do literackiego konceptu mitu sarmackiego. Mimo wiedzy na temat zasług plemion Amazonek oraz ich wpływu na ukształtowanie kultury sarmackiej zamojski poeta zdaje się zwolennikiem tezy o przewadze różnic nad podobieństwami między Sarmacją azjatycką a europejską, tym bardziej w zakresie ról życiowych kobiet i ich postrzegania w społeczeństwie. Wysuwając hipotezy o osobistych uprzedzeniach poety, nie można jednak w tym wypadku generalizować, jakoby Szymonowic był przeciwnikiem płci pięknej. Dowodzi tego wiersz Mulier fortis (1592), w którym poeta wymienia cnoty kobiet: ich pobożność, mądrość, roztropność, siłę i piękno. Niemniej jednak niewiasta z liryku autora Sielanek nadal stanowi tylko ozdobę swojego męża. Poeta nakreśla wizerunek kobiety, która jest wsparciem dla partnera i dopełnieniem jego duszy, choć nierzadko musi ona zmagać się z niemal tak samo ciężką fizyczną pracą, jak mężczyzna:

I dzielną ręką wiele robót nawiązała.

Stała się jako czujnych kupców rącze łodzi,

I chleb do domu swego $z$ obcych stron przywodzi.

Wstała z świtem i w gmachach porządek sprawiła,

Czeladź i służebnice strawą opatrzyła.

Skupiła żyzne włości, poszczepiła sady

Swą ręką, zamnożyła piękne winohrady.

${ }^{13}$ Literackie przedstawianie wad i słabości płci pięknej otworzyło pole do licznych dyskusji i polemik nad kwestią kobiecą w Polsce sarmackiej. W ówczesnym piśmiennictwie pojawiały się głosy obrońców kobiet. Przykładowo, Andrzej Glaber z Kobylina w swoich Gadkach o składności członków człowieczych uważał, że słabości wynikające z piękna i subtelności niewiast stanowią ich atuty, które nie powinny pozbawiać ich praw do nauki. Autor przekładu pism Miechowity uważał także, że brak dostępu do edukacji jest dla kobiet niesprawiedliwy i krzywdzący (Wojtkowska-Maksymik, 2017, s. 136-137). Glaber lepsze traktowanie kobiet widział w rozszerzaniu ich świadomości oraz otwarciu umysłów na świat, a zwłaszcza domagał się zaprzestania ich obrażania i umniejszania ich zasług w pełnionej przez wieki funkcji domowych opiekunek. W odniesieniu do Polek jego poglądy wciąż łączyły się ze stereotypem matki-chrześcijanki, która - owszem - powinna doskonalić się duchowo, jednak dalej winna żyć zgodnie z Dekalogiem i nakazem obyczajów. Poglądy Glabera i jemu współczesnych nie były na tyle postępowe, aby otworzyć temat dopuszczenia kobiet do męskich zawodów i takich aktywności, jak udział w polityce czy w militariach. Humanista uznawał tradycje kobiet walczących, o których z uznaniem wspominał za Plutarchem, powołując się na białogłowy rządzące bez udziału mężczyzn, w tym właśnie na Amazonki (Wojtkowska-Maksymik, 2017, s. 140). Jednakże nie łączył tego obrazu z polskimi kobietami. Stąd też debata na temat roli niewiast w społeczeństwie polskim w XVI i XVII wieku w gruncie rzeczy nie dotyka nawet zagadnienia kobiety jako heroiny oraz nie aktualizuje tego wizerunku w kontekście ówczesnych przemian światopoglądowych. 
Ujęła się w stateczność, wzięła władzą, siły

Wielmożne jej szlachetne ramię umocniły ${ }^{14}$.

(Mulier fortis, w. 8-16)

Zagadnienie ról kobiecych w dramacie Simonidesa można analizować także w aspekcie przestrzeni. Oto zaburzenie naturalnego porządku świata, za którym opowiadają się Pentezylea czy Deidamia, koliduje $\mathrm{z}$ bezpieczną formułą życia, z tym, co ustanowione od wieków w kulturze. Pole walki i towarzystwo żołnierzy stają się synonimem rewolucji oraz potencjalnym zagrożeniem anarchią. Z kolei świątynia Ateny to miejsce należące do rozmodlonych niewiast, które ufają boskiej opiece. Te dwie zmaterializowane przestrzenie życiowe kobiet są jak zderzenie zmiennej i stałej, końca i ciągłości, rozłamu i jedności. Na poziomie stosunku do rzeczywistości jest to również konfrontacja realizmu i metafizyki. Stała wartość duchowa w postaci modlitwy w świątyni Pallady ściera się z agresywnym przejawem fizycznej siły, jaką jest wojna na śmierć i życie.

Pentezylea jako bohaterka, w której pokładane były olbrzymie nadzieje, nie zdołała odwrócić losu kobiet. Mało tego - faktycznie nie dążłła do tej zmiany. Jeśli chcieć dosłownie potraktować przemowę protagonistki, trzeba przyjąć, że główną motywacją jej działań była chęć wypełnienia praw obowiązujących Amazonki (Masłowska-Nowak, 1990, s. 79). Jednakże jej chwiejna postawa i brak konsekwencji w dotrzymaniu postanowień co do strategii wojennej ujawniły jej osobistą, skrywaną przed innymi siłę napędową. W związku z tym w obrębie zagadnienia wielości pobudek, które nią kierowały, pojawiają się rozmaite problemy interpretacyjne. Niewykluczone, że w momencie wędrówki pod bramy Troi (Pentezylea, 2: w. 7-14) kobieta kierowała się tylko poczuciem obowiązku. Nie wiemy, co było wcześniej, dlatego prawdopodobnie jej motywacja ewoluowała wraz z przygotowaniami i kolejnymi etapami walki. Nie można zbagatelizować wewnętrznych rozterek heroiny, które wpływały na podejmowane przez nią decyzje. Stąd też czytelnik może odnosić wrażenie, że Amazonka postępowała egoistycznie, w głębi duszy nie myślała o innych, tylko o sobie. Stosunek do batalii przeciw Achajom mógł zdradzać jej prawdziwe pobudki. Zatem mógł być środkiem do osiągnięcia własnych celów, takich jak prawo do samorealizacji, równy dostęp do przywilejów, możliwość wyboru własnej drogi, a przede wszystkim wolność od męskiego osądu. Wymagania Amazonki były bardzo skonkretyzowane i spersonalizowane. Potępienie dosięgnęło heroinę dlatego, że w istocie nie zrealizowała ona ideałów „emancypacyjnych”, które deklarowała przed przystąpieniem do walki. Jednostkowa postawa okazała się niewystarczająca, aby odmienić losy kobiet, tym bardziej że bohaterka nie była do końca szczera w swoich altruistycznych motywacjach.

Takie rozbudowanie - jak na zamojskiego poetę - wątku kobiecego nasuwa wniosek, że głównej osi fabularnej tragedii nie wyznacza przedstawienie losów wojny trojańskiej, ale przeznaczenie jej bohaterów. Wszak płeć w tragedii Szymonowica można traktować jako kategorię, która implikuje nadchodzącą przyszłość. Stąd też wyraźnie zaakcentowano zasadność utrzymywania patriarchalnego sposobu funkcjonowania społeczeństwa. Wojna nie jest kwestią

14 Cyt. za: Szymonowicz, 1914, s. 119. 
kobiet - ich posłannictwem jest macierzyństwo i podtrzymywanie ogniska domowego. Ich siła sprawcza ogranicza się do tego, aby dawać życie przyszłym bojownikom. Z nakreślonej przez Simonidesa konkluzji wynika, że klęska Amazonek pod wodzą Pentezylei dowodzi, że kobiety nie mogą mieć wpływu na losy narodów, gdyż ich działania podyktowane są głupią ambicją, co grozi zagładą. Amazonka kreowana jest na bohaterkę destrukcyjną, która swoimi decyzjami pogrąża siebie i swoich podopiecznych. Poeta chce o tym zapewnić, umieszczając na końcu utworu epitafium dla Pentezylei, które ma być ostrzeżeniem dla wszystkich kobiet przed wchodzeniem w męskie role:

Mersa undis, superata armis, dum foemina sexum

Contra contendo, foemina sic perii.

Stultitiae exemplum muliebris, quod monet omnes,

Metiri ut proprio se pede quisque velit. ${ }^{15}$

(Pentesilea Epitafium, K: w. 1-4)

Zatopiona w falach, zwyciężona w walce, gdy jako kobieta przeciw [swej] płci występuję, tak jako kobieta zginęłam.

Przykład głupoty niewieściej, który napomina wszystkich,

aby każdy zechciał się mierzyć właściwą mu miarą.

Autor dramatu stworzył postać, której porażka jest bezpośrednim efektem jej porywczości i braku rozsądku. Innymi słowy, bohaterka tragedii Szymonowica to uosobienie kobiety przegranej. Jej działania są skazane na niepowodzenie, nie posiada ona bowiem naturalnej siły i przygotowania, aby wpływać na zdarzenia będące zaczynem historycznych opowieści.

\section{Bibliografia podmiotowa}

Quintus Smyrnaeus (1913). The fall of Troy. Ed. A.S. Way. Cambridge, Massachusetts: Harvard University Press.

Simonides, S. (1618). Pentesilea. Zamość: In officina Academiae, excudit Christophorus Wolbramensis.

Szymonowic, Sz. (1778). Pentezylea Simona Simonidesa. Z łacińskiego na polskie przełożona przez W. Jmci Xiędza Xawiera $z$ Werezub Zubowskiego. Warszawa: Drukarnia Mitzlerowska.

Szymonowicz, Sz. (1914). Sielanki (1614). I inne wiersze polskie. Wyd. J. Łoś. Kraków: Akademia Umiejętności.

15 Epitafium nie zostało uwzględnione w przekładzie Zubowskiego. Tutaj cyt. za: Simonides, 1618 (numeracja stron starodruku jest niepełna; epitafium znajduje się na ostatniej stronie). Korekta tłumaczenia - redakcja. 


\section{Bibliografia przedmiotowa}

Abramowska, J. (1974). Ład i fortuna. O tragedii renesansowej w Polsce. Wrocław: Ossolineum.

Bogucka, M. (1998). Kobieta w społeczeństwie polskim XVI-XVIII wieku na tle porównawczym.

Warszawa: Wydawnictwo Trio.

Bogumil, I. (2007). Adaptacje sceniczne czy dramaty? Antyczny epos jako źródło łacińskich tragedii i tragikomedii przełomu XVI i XVII wieku. Gdańsk: Wydawnictwo Uniwersytetu Gdańskiego.

Chmielowski, P. (1914). Historya literatury polskiej. Od czasów najdawniejszych do końca wieku XIX. T. 1. Lwów-Warszawa: Nakładem Księgarń: H. Altenberga, G. Seyfartha, E. Wendego i S-ki we Lwowie i E. Wendego i S-ki w Warszawie.

Genette, G. (1979). Gatunki, „typy”, tryby. Przekł. K. Falicka. Pamiętnik Literacki, 70 (2), 269-307.

Głębicka, E.J. (2001a). Penthesilea - nieudany dramat Szymona Szymonowica? Barok. Historia - Literatu$r a-S z t u k a, 16$ (2), 9-23.

Głębicka, E.J. (2001b). Szymon Szymonowic. Poeta Latinus. Warszawa: Instytut Badań Literackich PAN. Stowarzyszenie „Pro Cultura Litteraria”.

Graves, R. (1974). Mity greckie. Przeł. H. Krzeczkowski. Wstęp A. Krawczuk. Warszawa: Państwowy Instytut Wydawniczy.

Grimal, P. (1990). Słownik mitologii greckiej i rzymskiej. Przeł. M. Bronarska i inni. Wrocław: Zakład Narodowy im. Ossolińskich.

Hahn, W. (1895). Pentesilea. Dramat Szymona Szymonowica. Lwów: Główny skład w księgarni Gubrynowicza i Szmidta we Lwowie.

Hannam, J. (2010). Feminizm. Przeł. A. Kaflińska. Poznań: Wydawnictwo Zysk i S-ka.

Heck, K. (1903). Szymon Szymonowicz (Simon Simonides). Jego żywot i dzieła. Cz. 2-3. Kraków: Krakowska Akademia Umiejętności.

Janik, P. (2017). Amazonki - mit czy reminiscencja zwyczajów koczowniczych. Studia Azjatystyczne, 3, 61-76.

Krzyżanowski, J. (1926). Romans pseudohistoryczny w Polsce wieku XVI. Kraków: Wydział Nauki Ministerstwa Wyznań Religijnych i Oświecenia Publicznego.

Krzyżanowski, J. (1962). Romans polski wieku XVI. Warszawa: Państwowy Instytut Wydawniczy.

Kuchowicz, Z. (1990). Postawa wobec kobiety w kulturze szlacheckiej polskiego baroku. W: B. Jedynak (red.), Kobieta w kulturze i społeczeństwie (s. 7-50). T. 1. Lublin: Wydawnictwo Uniwersytetu Marii Curie-Skłodowskiej.

Łukaszewicz-Chantry, M. (2014). Kobieta jako postać literacka w łacińskiej poezji renesansowej. Wrocław: Wydawnictwo Uniwersytetu Wrocławskiego.

Malashev, V., Yablonsky, L. (2004). Early Nomads in the Southern Foothills of the Urals Based on Materials from the Pokrovka Burial-Ground. Ancient Civilization, 10 (3-4), 259-291.

Mańkowski, J. (1962). Historia trojańska w literaturze i kulturze polskiej wieku XVI. Meander, 17 (3), 137-147.

Masłowska-Nowak, A. (1990). Amazonki-greckie źródła literackie do historii mitu. Wrocław: Wydawnictwo Polskiej Akademii Nauk.

Mayor, S. (2014). The Amazons: Lives and Legends of Warrior Women across the Ancient World. Princeton: Princeton University Press.

Pauluk, D. (2005). Modele ról kobiety w podręcznikach do wychowania seksualnego. Kraków: Wydawnictwo Uniwersytetu Jagiellońskiego. 
Petrażycka-Tomicka, J. (1914). Z dziejów kobiety polskiej. Lwów: Skład Główny w Księgarni Gubrynowicza i Syna we Lwowie.

Pilat, R. (1909). Historyja literatury polskiej. Wykłady uniwersyteckie. Red. W. Bruchnalski. T. 2. Cz. 2: Następcy i naśladowcy Kochanowskiego. Oprac. S. Kossowski. Warszawa: Nakładem Księgarni H. Altenberga we Lwowie i M. Arcta w Warszawie.

Rusnak, R. (2008). Seneka - Kochanowski, Kochanowski - Seneka. Pamiętnik Literacki, 99 (3), 35-55.

Rusnak, R. (2011). „Virgo contra virum”. Kategoria płci w Pentesilei Szymona Szymonowica. W: W. Pawlak, M. Piskała (red.), Wojny, bitwy i potyczki w kulturze staropolskiej (s. 305-318). Warszawa: Instytut Badań Literackich PAN.

Sinko, T. (1935). Poezja nowołacińska w Polsce. W: T. Sinko (red.), Dzieje literatury pięknej w Polsce (s. 73-145). Cz. 1. Kraków: Nakładem Akademii Umiejętności.

Wojtkowska-Maksymik, M. (2017). Źródła i sposób ujęcia kwestii kobiecej godności w „O ślachetności a zacności płci niewieściej” Macieja Wirzbięty. Warszawa: Wydawnictwo Naukowe Sub Lupa \& Marta Wojtkowska-Maksymik.

Zielińska, A. (2012). Rola kobiety w plemionach koczowniczych, czyli w poszukiwaniu prawdziwych Amazonek. (The Role of Women in Nomadic Tribes, or in Search of the Real Amazons). W: W. Blajer (red.), Peregrinationes archaeologicae in Asia et Europa Joanni Chochorowski dedicatae (s. 427-434). Kraków: Wydawnictwo Profil-Archeo.

Ziomek, J. (2012). Literatura schyłku XVI wieku. W: J. Ziomek. Renesans (s. 411-447). Warszawa: Wydawnictwo Naukowe PWN.

\section{The role of women in "Pentesilea" drama by Szymon Szymonowic}

\section{Summary}

The purpose of the article is to analyze the roles of women described in the drama by Szymon Szymonowic entitled "Pentesilea". Continuing on the topic of the Trojan War and the accession of Pentezylea as the main heroine of this drama, it begins with a reflection on the woman's place in the world, her responsibilities, rights and privileges. The author describes the behavior of all women who appear in the text, shows the differnces xbetween them, their personalities and their opinions about gender. The conclusions from the article, in addition to the references on the situation of women from the previous centuries, also deal with the Szymonowic's personal views.

Słowa kluczowe: Pentesilea, role kobiet, Szymon Szymonowic, Amazonka, wojna trojańska Keywords: "Pentesilea”, women’s roles, Szymon Szymonowic, Amazon, Trojan War 